\title{
The Potential of Circ's Model in Poetry Learning at Higher Education
}

\author{
D P Yanda ${ }^{1}$, D Ramadhanti ${ }^{2}$, P D Afrinda ${ }^{3}$, I Bahardur ${ }^{4}$, M K Ihsan ${ }^{5}$ \\ $1,2,3,4,5$ STKIP PGRI Sumatera Barat, Indonesia \\ \{diyan@stkip-pgri-sumbar.ac.id ${ }^{1}$, dina@stkip-pgri-sumbar.ac.id², putri@stkip-pgri-sumbar.ac.id ${ }^{3}$, \\ iswadi@stkip-pgri-sumbar.ac.id ${ }^{4}$, khairiikhsan@stkip-pgri-sumbar.ac.id $\left.{ }^{5}\right\}$
}

\begin{abstract}
Understanding poetry is at the stage of enjoying poetry in the activity of appreciating poetry. From the stage of enjoying this poem, poetry lovers can determine their attitude towards the poetry that is read or heard. By integrating reading and writing, poetry readers can enjoy poetry in depth. Therefore, this study aims to describe the potential of the CIRC learning model in influencing the ability to understand poetry. A total of 28 male and female students were selected as participants in the study. The instrument used to collect research data is a multiple choice test understanding poetry. The method used was preexperiment with the design of one group pretest-posttest study. The CIRC model in this study is used in the process of poetry learning. This model is used by the way the lecturer places students in cooperative learning activities according to the learning objectives, students understand the subject matter together in groups by way of reading to each other and finding keywords according to the learning objectives and presenting the results of group collaboration in the form of class discussions. Group discussions and class discussions provide opportunities for students to voice their opinions about the contents of poetry. Students who have low abilities are motivated to learn because of teamwork. The CIRC model has the potential to improve student language skills, improve social skills among students, and have a positive impact on reading comprehension, especially understanding poetry.
\end{abstract}

Keyword: Cooperative, Reading, Composition, Poetry

\section{INTRODUCTION}

Cooperative learning has been used as the most powerful learning model in several countries and has proven effective used in the learning process. In Turkey, cooperative learning is applied to help improve reading comprehension of English [1]. In Taiwan, cooperative learning is used to reduce the level of anxiety of learning foreign languages for American and Taiwanese students [2]. In addition, cooperative learning is also used in the science classes and has been shown to have an impact on increasing group collaboration because learning is done in teams ([3], [4]), so that students are actively involved in the learning process. In the language class, cooperative learning is applied in the process of reading comprehension learning and proven to have a significant impact on the results of 
reading comprehension of students ([5], [6], [7], [8]). In general, cooperative learning models have an impact on teamwork and reduce students' anxiety levels in the learning process.

Some of the cooperative learning models are applied in the learning process. One of them is the Cooperative Integrated Reading and Composition (CIRC) model (For the next written and read CIRC). The CIRC model is an integrated learning model between reading and writing in the learning process. For example, in Korea, learning by integrating reading and writing has an influence on the ability to read and write students [9]. As with other cooperative learning models, the CIRC model also influences the quality and achievement of students in understanding reading [10]. In addition, the CIRC model also has an impact on structuring and content in writing, for example in writing recount texts [11] and writing narrative texts [12]. With the CIRC model, students have the opportunity to share ideas in producing writing.

To realize the quality's of learning, the CIRC model is aligned with various factors, such as reading interest [13], motivation to learn [14], reading habits [15], and the level of anxiety in language learning [5]. Students who have high interest and motivation to read show good sensitivity in the learning process, whereas students who have an interest and low reading motivation are increasingly motivated in the learning process. The CIRC model is able to grow students' reading habits and reduce students' anxiety levels in learning, especially those who have low interest and reading motivation.

Learning with the CIRC model has been applied at College Education. One of them is in Biology learning. The results show that the CIRC model has the potential to improve the quality of Biology learning at College Education [16]. Unfortunately, there are not many who apply this CIRC model at College Education, especially in language learning. During this time, teachers and lecturers were too bound by the assumption that CIRC was only applied in learning at the elementary and secondary levels. In fact, the cooperative model that integrates reading and writing in the learning process provides benefits in improving students' language arts [17], besides improving thinking skills, communication skills, and social skills. Students are taught to understand and appreciate language art directly so that the teacher will have comfort in teaching poetry to students [18]. Problems related to literature learning, especially poetry can be overcome. One of them is by choosing a learning model that can improve language arts and literary students. Therefore, in this study CIRC models will be applied assuming that this model has good potential in improving the quality of poetry learning.

\section{RESEARCH METHOD}

This research was an experimental study using a pre-experimental design, one group pretest-posttest study [19]. This design is also called pseudo-experimental because this study follows experimental research procedures, but no control conditions or control group are used [20]. This research was only conducted to investigate the relationship of sample groups to the phenomena or treatments given and changes that occurred in the group, namely changes in learning outcomes understanding poetry in one group before and after the CIRC learning model was used.

The group observed as participants in this study were the students of Indonesian Language and Literature Education Study Program who studied at STKIP PGRI Sumatera Barat. A total of 28 people from 124 male and female students were selected by choosing one class that had the lowest Poetry Appreciation ability among the other classes to be used as the research sample. These students are students who take a poetry class on the subject of "Apresiasi Puisi Indonesia." 
The instrument used as a tool to collect data in research is a multiple choice question of understanding poetry. Multiple choice test questions are arranged based on the physical structure and inner structure of poetry. The questions tested consist of 50 items. These questions have been compiled, validated and tested [21]. To make it easier for students in the learning process to understand poetry with the CIRC model, they are facilitated with the book "Memahami Puisi". The book contains material on the introduction of poetry, understanding the elements of form and content of poetry, understanding the elements of sound in poetry, understanding the elements of language in poetry, understanding the elements of imagery in poetry, understanding aspects of figurative language in poetry [22].

This study used the pre-experimental with one group pretest-posttest design. During treatment, a CIRC model was applied with three basic components, namely: basic activities related to cooperative learning, reading comprehension, and integrated writing activities: (a) the basic activities related to cooperative learning carried out by students are to provide material for activities to understand and analyze poetry in the learning process, both in pairs and groups, (b) understanding poetry given by identifying key ideas related to the structure inner and physical structure of poetry, and make conclusions, (c)Students write of short essays about poetry[23]. After treatment with the CIRC model was completed, students were given multiple choice tests to understand poetry. Data analysis was performed using the SPSS 23 data processing application.

\section{RESULT AND DISCUSSION}

In this section, the results of learning to understand poetry, both before and after the application of the CIRC model will be explained. These results are presented based on statistical testing. The frequency distribution of poetry learning results before applying the CIRC model is as follows. There were 28 valid participants and none of them were lost. Central data tendencies, namely: the mean is 38.71 ; the median is 38.00 ; mode is 30.00 ; and the total score is 1084.00 . Data dispersion, namely: the minimum score is 24.00 ; the maximum score is 52.00 ; the range is 28.00 ; the data variant is 59.02 ; the standard deviation is 7.68 ; and the standard error of the mean is 1.45 . Furthermore, the distribution of data is seen based on the value of the skewness ratio and the value of the kurtosis ratio. Skewness ratio value is obtained from the results of the skewness value with the standard error of skewness value. The skewness ratio obtained is 0.03 . The value of the kurtosis ratio obtained is -1.03 . Skewness ratio value and kurtosis ratio value are between -2 to +2 , meaning that the distribution of data is normally distributed. The data distribution is visualized in the form of Figure 1 below.

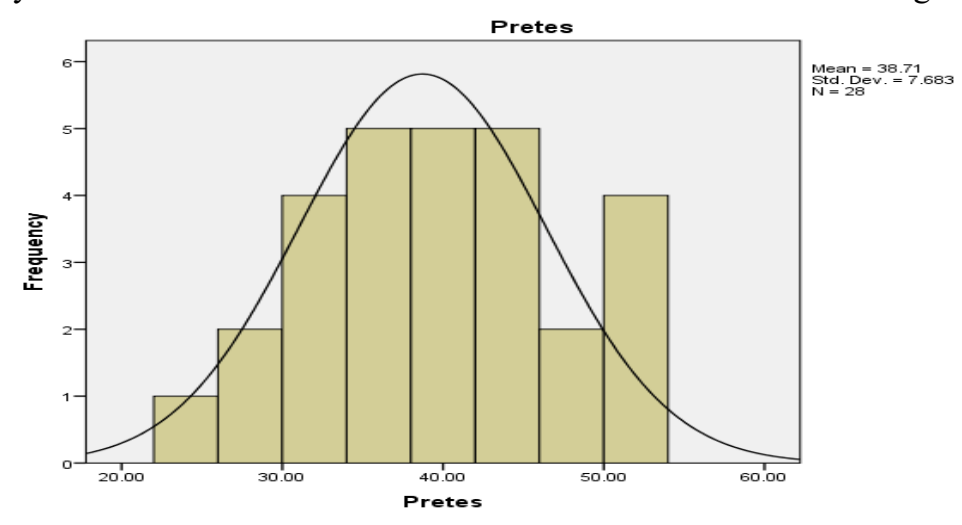


Figure 1. Distribution of Learning Outcomes Data before Application of the CIRC Model

The frequency distribution of poetry learning results after applying the CIRC model is as follows. There were 28 valid participants and none of them were lost. Central data tendencies, namely: the mean is 73.36 ; the median is 68.00 ; mode is 60.00 ; and the total number of scores is 2054.00. Data dispersion, namely: the minimum score is 54.00; the maximum score is 92.00; the range is 38.00 ; the data variant is 150.53 ; the standard deviation is 12.27 ; and the standard error of the mean is 2.32. Furthermore, the distribution of data is seen based on the value of the skewness ratio and the value of the kurtosis ratio. Skewness ratio value is obtained from the results of the skewness value with the standard error of skewness value. The skewness ratio obtained is 0.22 . The value of the kurtosis ratio obtained is -1.86 . Skewness ratio value and kurtosis ratio value are between -2 to +2 , meaning that the distribution of data is normally distributed. Data distribution is visualized in the form of Figure 2 below.

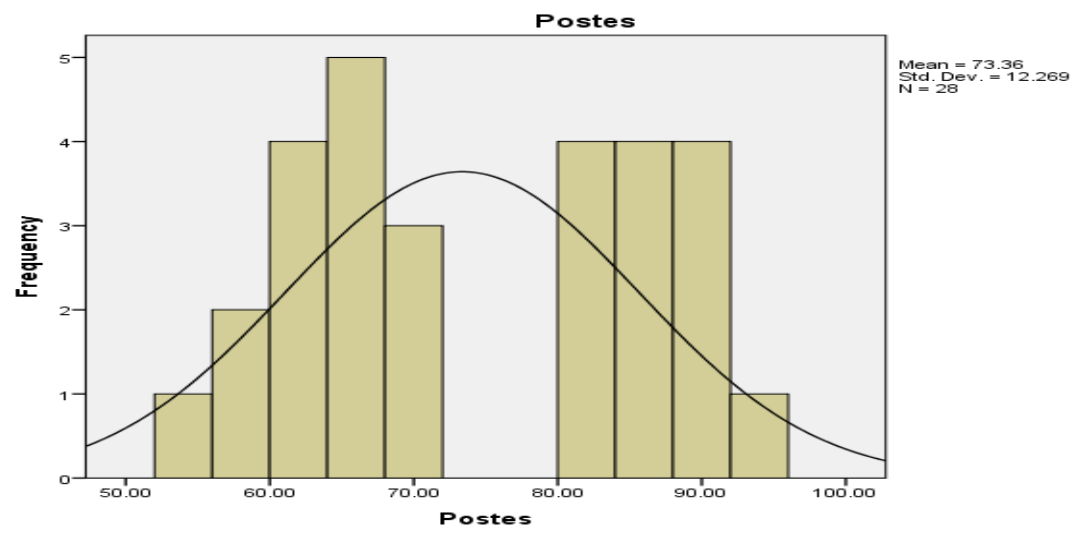

Figure 2. Distribution of Learning Outcomes Data after Application of the CIRC Model

In Table 3 the following will be presented the results of statistical testing of the results of poetry learning.

Table 3. The testing t-test Learning Outcomes

\begin{tabular}{lrr}
\hline & \multicolumn{2}{c}{ Pair 1 } \\
\cline { 2 - 3 } & \multicolumn{1}{c}{ Posttest } & Pretest \\
\hline Mean & 73.3571 & 38.7143 \\
$\mathrm{~N}$ & 28 & 28 \\
Std. Deviation & 12.26925 & 7.68287 \\
Std. Error Mean & 2.31867 & 1.45193 \\
\hline
\end{tabular}

Paired Samples Test

\begin{tabular}{|c|c|c|c|}
\hline & & & Pair 1 \\
\hline & & & Posttest - Pretest \\
\hline Paired & Mean & & 34.64286 \\
\hline Differences & Std. Deviation & & 5.07875 \\
\hline & Std. Error Mean & & .95979 \\
\hline & $95 \%$ Confidence Interval of & Lower & $\begin{array}{l}32.67353 \\
3661210\end{array}$ \\
\hline & the Difference & Upp & 36.61219 \\
\hline
\end{tabular}




\begin{tabular}{|l|r|}
\hline $\mathrm{T}$ & 36.094 \\
$\mathrm{Df}$ & 27 \\
Sig. (2-tailed) & .000 \\
\hline
\end{tabular}

Based on the results of data analysis the results showed that the posttest score mean to understand poetry was 73.36 higher than the mean pretest score understanding poetry which was 38.71 with a difference of 34.65. The results of the analysis of different tests (t-tests) posttest scores understanding poetry and the pretest score of understanding poetry were 36.09 $(p=0.00)$. These results indicate that there is a significant difference between posttest scores understanding poetry with a pretest score understanding poetry $(\mathrm{p}<0.01)$. It can be concluded that there is a (rising) influence on the use of the CIRC model on the skill of understanding poetry. The research hypothesis formulated in the form of: "there is the influence of using the CIRC model on the skills to understand poetry" was accepted.

The CIRC model is a cooperative learning model that is carried out with three basic components, namely: basic activities related to cooperative learning, reading comprehension, and integrated writing activities [23]. The basic activities related to cooperative learning according to the purpose of learning are understanding and analyzing the poetry given by the lecturer. The activities carried out by students are aimed at applying theory according to the learning objectives, namely analyzing the inner structure and physical structure of poetry. The final goal of learning is that students can understand and interpret the poetry they read. After the lecturer explains the learning outcomes and introductory material to understand poetry, students are given a poem titled "Tentang Seorang Penjaga Kubur yang Mati" by Sapardi Djoko Damono. These poems are discussed in pairs or in groups. In heterogeneous groups, each student together reads each other's poems, finds keywords in poetry that show the building elements of poetry, namely the physical structure and inner structure of poetry. Students in groups work together and given the response. The collaborative results are presented in writing in the form of the results of the analysis of understanding poetry. Then the students carry out class discussions. Class discussions are conducted with the aim that they can give input to each other on collaborative results in each group. Each group gave input on the collaborative results. The lecturers together with students reflect on the activities carried out by testing each student in understanding poetry to find out that students have been able to understand and interpret the poetry they read.

The activities carried out have an impact on improving the learning outcomes of understanding poetry. Improving student learning outcomes is influenced by the learning model used. Students who at first had difficulty understanding poetry in terms of the physical structure and inner structure of poetry became more skilled at understanding poetry. In heterogeneous study groups, they are directed to be able to understand poetry step by step. They came to understand how to find keywords that showed the building blocks of poetry. In terms of interpreting the meaning or content of poetry, student interpretation varies because they have different experiences and knowledge. Poetry learning is prioritized on the affective development of students, to enrich their experience [24], and serves as a creative practice of students [25]. In general, their learning outcomes provide enough evidence that they are skilled at understanding the building blocks of poetry, namely the physical structure and inner structure of poetry. This is consistent with the theory that the constructing element of poetry consists of the physical structure and inner structure of poetry. The physical structure of poetry consists of typography, imagery, concrete words, figurative language, and verification and the inner structure of poetry consists of themes, feelings, tones, and messages[22]. Students 
understand poetry in terms of the element of the poem, then interpret the things contained in the poetry they read.

Unlike previous learning, students make a summary of the material of learning and discuss them in front of the class. Student written reports tend to be mere copies of theory without training and practice in understanding and interpreting poetry. It turned out that this did not have a significant effect on student learning outcomes. Students are not skilled in interpreting poetry. When they are faced with different poems they find it difficult to determine the things contained in the poem. This even affected their skills in writing poetry. They can produce writing but it cannot be said as a poem. That in writing poetry also must be considered the elements that make up the poem. In terms of the process, there is no student enthusiasm for learning. This is evidenced by the results of the pretest that student grades are far below the average. They are not skilled at understanding poetry from the physical structure and inner structure of poetry.

After learning with the CIRC model, student learning outcomes are statistically increased. Learning outcomes before and after learning with the CIRC model show significant differences. Students in the process also seemed enthusiastic in the learning process. This is evident from the results of observations made on the poetry learning process, both when discussions in heterogeneous study groups and when class discussions take place. Students in their study groups discuss each other, all group members are actively involved in learning. The CIRC model is proven to effectively improve student learning processes and outcomes in understanding poetry. In addition to improving the process and learning outcomes, the CIRC model has a long-term effect on students in developing reading skills, even children who have academic disabilities can increase their level of understanding in reading [26].

Student learning outcomes are increasing because of the learning pattern that makes the relationship between lecturers and students more mediated in the classroom [27]. Students have collaboration in groups and teachers can comment on student performance results more organized. In other words, the verbal behavior of lecturers in the classroom is influenced by students of class organizations [28]. One of them, the application of discussion in heterogeneous groups so that students who have a high ability can work together with students who have the low ability. Group learning makes students more enthusiastic about voicing and debating their ideas, accepting and sharing responsibility for their own learning, reflecting on their own thinking and being more aware of their own decision-making and problem-solving skills [4]. With collaboration in groups, in addition to improving the learning outcomes of reading and writing, cooperative learning also enhances student social skills [17].

\section{CONCLUSIONS}

The use of the CIRC model has a significant influence on the learning outcomes of understanding poetry. Learning in heterogeneous groups provides more opportunities for students to discuss poetry given by lecturers. In study groups, they read to each other, find keywords, and conclude the elements of poetry according to the learning objectives. Students are taught to understand poetry step by step starting from understanding poetry, finding elements of poetry, and interpreting poetry. Students can express their opinions on the content of poetry according to their experience and lecturers can comment on the performance of students according to the stages of learning. Thus, the purpose of literary learning, especially poetry to enrich student experience can be realized by applying the CIRC model in the learning process. 


\section{REFERENCES}

[1] F. Bolukbas, F. Keskin, and M. Polat, "The effectiveness of Cooperative Learning on the Reading Comprehension Skills in Turkish as a Foreign Language," Turkish Online J. Educ. Technol., vol. 10, no. 4, pp. 330-335, 2011.

[2] J. G. Duxbury and L. Tsai, "The Effects of Cooperative Learning on Foreign Language Anxiety: A Comparative Study of Taiwanese and American Universities," Int. J. Instr., vol. 3, no. 1, pp. 3-18, 2010.

[3] C. F. Herreid, "Team Learning: Cooperative Learning in the Science Classroom," Natl. Cent. Case Study Teach. Sci., pp. 1-11, 2000.

[4] E. Lin, "Cooperative Learning in the Science Classroom," Sci. Teach, vol. 73, no. 5, pp. 122-125, 2006.

[5] G. Ghaith, "Effects of the Learning Together Model of Cooperative Learning on English as a Foreign Language Reading Achievement, Academic Self-Esteem, and Feelings of School Alienation," J. Natl. Assoc. Biling. Educ., vol. 27, no. 3, pp. 451-474, 2003.

[6] A. Jalilifar, "The Effect of Cooperative Learning Techniques on College Students' Reading Comprehension," System, vol. 38, no. 1, pp. 96-108, 2010.

[7] S. G. Nejad and A. Keshavarzi, "The Effect of Cooperative Learning on Reading Comprehension and Reading Anxiety of Pre-University Students," J. Appl. Linguist. Lang. Res., vol. 2, no. 8, pp. 169-180, 2015.

[8] A. D. Endeshaw, "The Effect of Cooperative Learning on Students' EFL Reading Comprehension: Meshentie Grade Nine High School Students in Focus," Educ. J., vol. 4, no. 5, pp. 222-231, 2015.

[9] H. Cho and J. B. Griffler, "Integrated Reading and Writing : A Case of Korean English Language Learners," Read. a Foreign Lang., vol. 27, no. 2, pp. 242-261, 2015.

[10] M. Gupta and J. Ahuja, "Cooperative Integrated Reading Composition (CIRC): Impact on Reading Comprehension Achievement in English Among Seventh Grades," Int. J. Reasearch Humanities. Arts, Lit., vol. 2, no. 5, pp. 37-46, 2014.

[11] F. Mustafa and N. M. A. Samad, "Cooperative Integrated Reading and Composition Technique for Improving Content and Organizing in Writing," Stud. English Lang. Educ., vol. 2, no. 1, pp. 29-44, 2015.

[12] D. Ramadhanti, "Penerapan Model Kooperatif Tipe CIRC dalam Pembelajaran Menulis Narasi Siswa Kelas VII SMP Negeri 2 Lembah Gumanti.," Gramatika, vol. 3, no. 1, pp. 27-42, 2017.

[13] A. Donal and B. Niati, "The Implementation of Cooperative Integrated Reading and Composition in Reading Interest," J. English Educ., vol. 3, no. 2, pp. 49-54, 2017.

[14] H. Mubarok and N. Sofiana, "Cooperative Integrated Reading and Composition (CIRC) and Reading Motivation: Examining the Effect on Students' Reading Ability," Ling. Cult., vol. 11, no. 2, pp. 121-126, 2017.

[15] H. Mubarok and N. Sofiana, "Examining the Impact of Teaching Strategies and Reading Habits on Students' Reading Comprehension," Lensa Kaji. Kebahasaan, Kesusastraan, dan Budaya, vol. 8, no. 2, pp. 189-202, 2018.

[16] R. H. Ristanto, S. Zubaidah, M. Amin, and F. Rohman, "The Potential of Cooperative Integrated Reading and Composition in Biology Learning at Higher Education," Int. J. Educ. Res. Rev., vol. 3, no. 1, pp. 50-56, 2018.

[17] K. Bromley and M. Modlo, "Using Cooperative Learning To Improve Reading and Writing in Language Arts," Read. Writ. Q., vol. 13, no. 1, pp. 21-35, 1997.

[18] S. Cronmiller, "Essential Poetry: Activating the Imagination in the Elementary 
Classroom," J. Learn. Through Arts A Res. J. Arts Integr. Sch. Communities, vol. 3, no. $1,2007$.

[19] I. Horvath, "Theory Building in Experimental Design Research," in Experimental Design Research: Approaches, Perspectives, Applications, P. Cash, T. Stankovic, and M. Storga, Eds. Switzerland: Springer, 2016, pp. 209-231.

[20] P. Cash, T. Stankovic, and M. Storga, "An Introduction to Experimental Design Research," in Experimental Design Research: Approaches, Perspectives, Applications, P. Cash, T. Stankovic, and M. Storga, Eds. Switzerland: Springer, 2016, pp. 3-12.

[21] D. Ramadhanti and D. P. Yanda, "Understanding Poetry Through the Use of Cooperative Learning Model," Cakrawala Pendidik., vol. XXXVII, no. 3, pp. 436-446, 2018.

[22] D. Ramadhanti and D. P. Yanda, Memahami Puisi. Yogyakarta: Deepublish, 2017.

[23] R. E. Slavin, Cooperative learning: Theory, Research, and Practice, 2nd ed. Boston: Allyn and Bacon, 1994.

[24] J. Hennessy, C. Hinchion, and P. M. Mcnamara, "Poetry and Pedagogy: Exploring the Opportunity for Epistemological and Affective Development within the Classroom," Lit. Inf. Comput. Educ. J., vol. 1, no. 3, pp. 178-185, 2010.

[25] S. R. Januchowski et al., "Poetry as a Creative Practice to Enhance Engagement and Learning in Conservation Science," Bioscience, vol. 68, no. 11, pp. 905-911, 2018.

[26] R. Steven and R. E. Slavin, "Effect of a Cooperative Learning Approach in Reading Writing on Academically Handicapped and non-Handicapped Student," Elem. Sch. J., vol. 95, pp. 241-262, 1995.

[27] K. Saddhono and M. Rohmadi, "A Sociolinguistics Study on the Use of the Javanese Language in the Learning Process in Primary Schools in Surakarta, Central Java, Indonesia." Int. Edu. Stu., vol. 7 no.6 pp 25-30, 2014

[28] R. M. Gillies, "Teachers' and students' verbal behaviours during cooperative and smallgroup learning," Br. J. Educ. Psychol., vol. 76, no. 2, pp. 271-287, 2006. 